\title{
Non Linear Static Analysis Of Knee Bracing In Steel Frame Structures
}

\author{
R.S. Londhe* and M.F.Baig \\ Department of Applied Mechanics, Government Collage of Engineering, Station Road, Aurangabad - 431005 \\ (M.S), India
}

\begin{abstract}
In order to dissipate input earthquake energy in the moment resisting frame (MRF) and concentrically braced frame $(C B F)$, inelastic deformation in main structural members, requires high expense to repair or replace the damaged structural parts. The proposed knee braced frame $(K B F)$ is a steel frame structure in which the diagonal brace provide most of the lateral stiffness and the knee anchor that is a secondary member, provides ductility through flexural yielding. In this paper the results and analysis on affects of knee bracings on steel structure is provided by considering non linear static pushover analysis of knee braced framed structure . various parameters such as ductility, base shear, displacement is studied by analysis of moment resisting frame and other types of knee braced frames on Sap2000. finite element modelling software.
\end{abstract}

Key Words: knee braced frame, pushover analysis, demand capacity curves, hinge formations, displacement at performance point

\section{Introduction}

Structures designed to resist moderate and frequently occurring earthquakes must have sufficient stiffness and strength to control deflection and to prevent damage However, it is inappropriate to design a structure to remain elastic under severe earthquake because of economic constraints. The inherent damping of yielding structural elements can be advantageously utilized to lower the strength requirements, leading to a more economical design. This yielding provides ductility or toughness of structure against sudden brittle type structural failure. Since stiffness and ductility are generally to opposing properties, it is desirable to devise a structural system that combines these properties in most effective manner without excessive increase in cost.

In steel structures, the moment resisting and concentrically braced frames have been widely used to resist earthquake loadings. The moment resisting frame possesses good ductility through flexural yielding of beam element but it has limited stiffness. The concentrically braced frame on other hand is stiff, but because of buckling of diagonal brace its ductility is limited.

[3] Aristizabal Ochoa has proposed a framing system which combines the stiffness of diagonal brace with ductile behavior a knee element. This system as originally proposed, however was not suitable for earthquake-resistant design because the brace was designed to be slender, the brace will buckle and leads to pinching of hysteresis, which is not energy dissipating. Further, inelastic cyclic deformation of brace which buckles may create a lateral instability problem at knee braced joint and cause sudden change to restoring force of structure.

Subsequently, [4] Balendra re-examined the system and proposed modification to it. The revised system presented here is called knee brace frame.

Here in this paper a five storey moment resisting frame building is designed and pushover analysis is carried out on eight different type of knee braced frames along with the basic basic moment resting frame structure.

Knee braced frames are compared for :

a) Knee and brace section required at performance point

b) Displacement at performance point

c) Ductility offered

Total height is $15 \mathrm{~m}$ with equal storey height of $3 \mathrm{~m}$ and $6 \mathrm{~m}$ bay width. A 2D frame is selected for pushover analysis.

\section{Non-Linear Static Analysis}

The pushover analysis can be considered as a series of incremental static analysis carried out to examine the non linear behavior of structures, including the deformation and damage pattern . The procedure consist of two parts, First a target displacement for the structure is established. The target displacement is an estimate of seismic top of the building, when it is exposed to the design earthquake excitation. Then, a pushover analysis is carried out on the structure until the displacement at the top of the building reaches the target displacement. The extent of damage experienced by the building at target displacement is considered to be the 
representative of the damage experienced by the building when subjected to design level ground shaking. The use of static pushover analysis in seismic design is growing rapidly in popularity. A non-linear static analysis is performed under a small number of pre-defined load patterns. The pushover curve is simplified to an idealized SDOF form and this is then used together with the design response spectrum to determine the peak displacement under the design earthquake - termed the target displacement or performance point. The non-linear static analysis is then revisited to determine the member forces and deformations at this point.

\subsection{Knee Brace System Definition}

The knee bracing steel frame (KBF) is energy dissipating frame system, which combines excellent ductility and lateral stiffness. The knee element is a fuse-like element that dissipates energy by the formation of plastic flexural hinges at its ends and mid-span when the building is subjected to severe lateral loads. The diagonal brace element, on the other hand, provides the required level of lateral stiffness and remains in the elastic range at all time.

In this system, the non buckling diagonal brace provides most of the lateral stiffness. The ductility under a severe earthquake is provided by the flexural yielding of the knee element. In this way, the damage is concentrated in a secondary member which can be easily repaired at minimum cost. Floor distortions are reduced compared to the EBF, to a level similar to that of the conventional moment-resisting and concentrically braced frames.

In Fig. 1 different types of KBF systems are shown. They are referred to as.

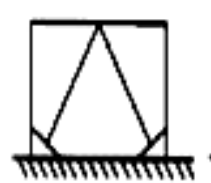

(a)

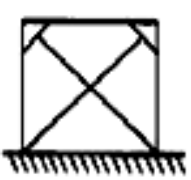

(b)

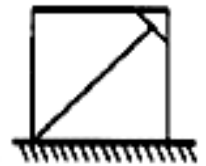

(c)

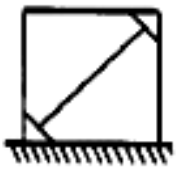

(d)

Figure 1 : Types of knee brace frames

(a) K-knee braced frame (b) X-knee braced frame (c) knee braced frame with single brace and one knee element (d) knee braced frame with single brace and with two knee elements.

\section{Structural Model}

The optimal shape of KBF is selected from the above systems according to the elastic analysis results of them. And the optimal angle of the knee element achieved when the frame has the maximum stiffness, which the tangential ratio of $(\mathrm{b} / \mathrm{h}) /(\mathrm{B} / \mathrm{H})$ is nearly one, it means that the knee element should be parallel to the diagonal direction of the frame, and the diagonal element passes through the midpoint of the knee element and the beamcolumn intersection, as shown in Fig. 2

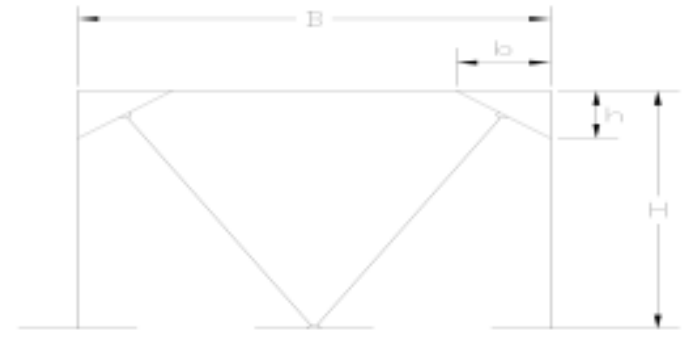

Figure 2 : Beam- coloumn intersection of knee bracing 


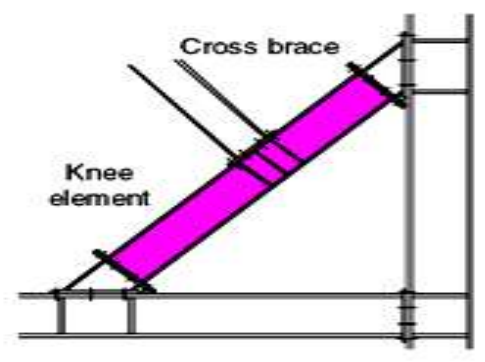

Figure 3 : Typical Knee element Configuration

\section{THEROTICAL ANALYSIS}

Here in this paper pushover analysis done in SAP2000 NL

here first of all a five storey moment resisting frame structure is designed and pushover analysis of moment resisting frame is carried out and eight different type of knee braced frames are analyzed and these knee braced frames are compared for :

a) Knee and brace section required at performance point

b) Displacement at performance point

c) Ductility offered

Total height is $15 \mathrm{~m}$ with equal storey height of $3 \mathrm{~m}$ and $6 \mathrm{~m}$ bay width. A 2D frame is selected for pushover analysis, considering parameters from IS1893-2005 (part IV), IS1893-2002 (part I), sections as per IS 800

\section{Member Section}

TABLE I : Specified dimensions to members

\begin{tabular}{|c|c|c|c|c|}
\hline Storey & \multicolumn{2}{|c|}{ Column } & Beam & Section Type \\
\hline & Outer & Inner & & \\
\hline 1 & ISWB400 & ISHB450 & ISHB400 & I/Wide Flange \\
\hline 2 & ISWB400 & ISHB350 & ISHB400 & I/Wide Flange \\
\hline 3 & ISWB300 & ISHB300 & ISHB400 & I/Wide Flange \\
\hline 4 & ISMB350 & ISWB350 & ISHB400 & I/Wide Flange \\
\hline 5 & ISMB350 & ISWB200 & ISHB400 & I/Wide Flange \\
\hline
\end{tabular}

TABLE II : Connections patterns

\begin{tabular}{|c|c|c|}
\hline $\begin{array}{c}\text { Beam-Column } \\
\text { Connection }\end{array}$ & $\begin{array}{c}\text { End of Braced } \\
\text { Connection }\end{array}$ & $\begin{array}{c}\text { Knee Beam- } \\
\text { Knee Column } \\
\text { Connections }\end{array}$ \\
\hline Pinned & pinned & rigid \\
\hline
\end{tabular}

LOADING PARAMETERS

Loading on beam is as follows

DEAD LOAD - $28.5 \mathrm{KN}$

LIVE LOAD- $18 \mathrm{KN}$

Seismic force calculation

Zone factor (z) V - Importance factor (I) -1

Response reduction factor(R)- 4

Base shear $=V_{b}=A_{h} \times \sum W_{i}=274.400 \mathrm{KN}$ 


\section{Member seismic forces}

TABLE III : Member seismic forces details

\begin{tabular}{|l|c|l|l|l|l|}
\hline $\begin{array}{l}\text { floor } \\
\text { wgt. }\end{array}$ & Hgt. & $W_{i} h_{i}^{2}$ & $\sum W_{i} h_{i}^{2}$ & $\frac{W_{i} h_{i}^{2}}{\sum W_{i} h_{i}^{2}}$ & $\begin{array}{l}\mathrm{Q} i=\mathrm{V} b \\
\mathrm{x} \frac{W_{\mathrm{i}} h_{i}^{2}}{\sum W_{i} h_{i}^{2}}\end{array}$ \\
\hline 594 & 3 & 53460 & 294030 & 0.01818181 & 4.98910 \\
\hline 594 & 6 & 21384 & 294030 & 0.0727272 & 9.95640 \\
\hline 594 & 9 & 48114 & 294030 & 0.16363636 & 4.90191 \\
\hline 594 & 12 & 85536 & 294030 & 0.29090909 & 9.82562 \\
\hline 594 & 15 & 13365 & 294030 & 0.45454545 & 24.7275 \\
\hline
\end{tabular}

\section{ANALYSIS}

Using the Pushover analysis data two pushover cases are defined. These are PUSH1:for gravity loads, which is force controlled Pushover analysis. PUSH2: for lateral loads, which is displacement controlled pushover analysis, it is to be followed by gravity pushover case. Load profile is parabolic as per IS 1893-2002 by seismic coefficient method. After pushover analysis is done, hinge pattern is observed .A chevron knee braced frame is shown in fig. 4 In this type, two braces are connected in such way that line of action of brace will pass through beam column intersection. Connection of knee element with beam column is rigid and with brace is pinned.

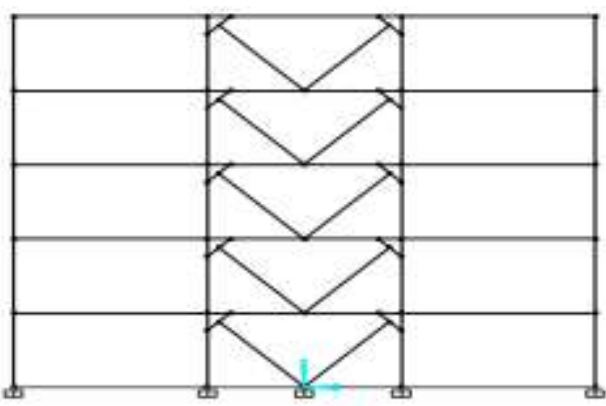

Figure 4 : Chevron knee brace frame model

TABLE IV : Knee-brace sections assigned

\begin{tabular}{|c|c|c|}
\hline STOREY & KNEE & BRACE \\
\hline 1 & ISLB125 & ISLB125 \\
\hline 2 & ISLB125 & ISLB125 \\
\hline 3 & ISLB125 & ISLB125 \\
\hline 4 & ISLB100 & ISLB125 \\
\hline 5 & ISLB75 & ISLB75 \\
\hline
\end{tabular}

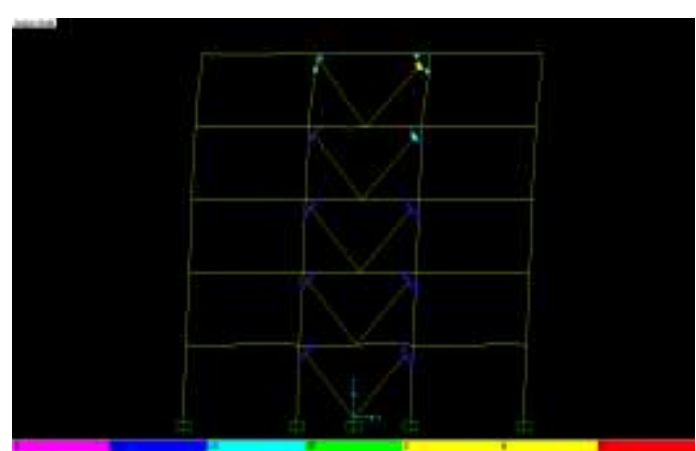

Figure 5 : Hinge formation at performance point

TABLE V : Revised knee-brace sections

\begin{tabular}{|c|c|c|}
\hline STOREY & KNEE & BRACE \\
\hline 1 & ISLB125 & ISLB250 \\
\hline 2 & ISLB150 & ISLB275 \\
\hline 3 & ISLB150 & ISLB275 \\
\hline 4 & ISLB125 & ISLB250 \\
\hline 5 & ISLB100 & ISLB200 \\
\hline
\end{tabular}



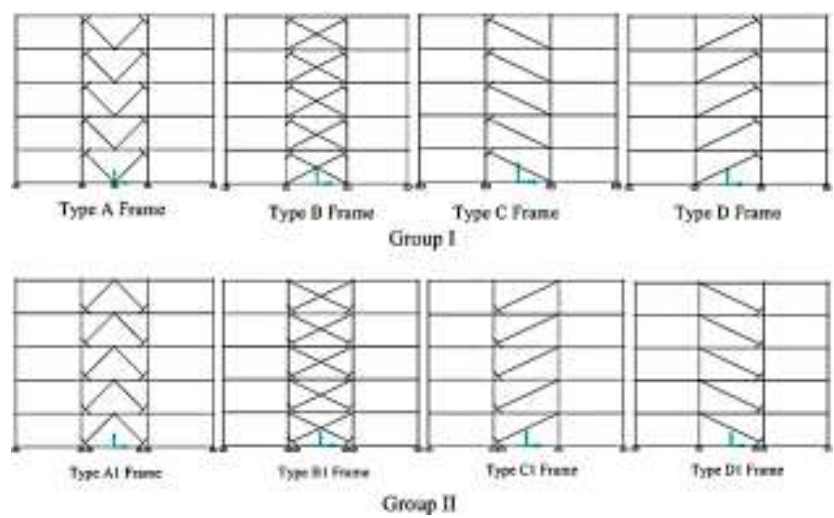

Figure 6 : Types of knee braced models analysed

(a) K-knee braced frame (b) X-knee braced frame (c) knee braced frame with single brace and one knee element on left top (d) knee braced frame with single brace and one knee element on right top , group II is exactly opposite to group I.

Likewise 7 other types of knee bracings frames with different combinations as shown in fig. 6 are studied and analysed and their respective results are as follows :-

\section{Base shear at Performance point}

TABLE VI: Base shear and Performance point details

\begin{tabular}{|c|c|c|}
\hline SR.NO. & TYPE OF FRAME & BASE SHEAR (KN) \\
\hline 1 & MRF & 763.11 \\
\hline 2 & A & 570.342 \\
\hline 3 & B & 640.40 \\
\hline 4 & C & 560.151 \\
\hline 5 & D & 586.003 \\
\hline 6 & A1 & 664.77 \\
\hline 7 & B1 & 602.502 \\
\hline 8 & C1 & 700.732 \\
\hline 9 & D1 & 586.003 \\
\hline
\end{tabular}

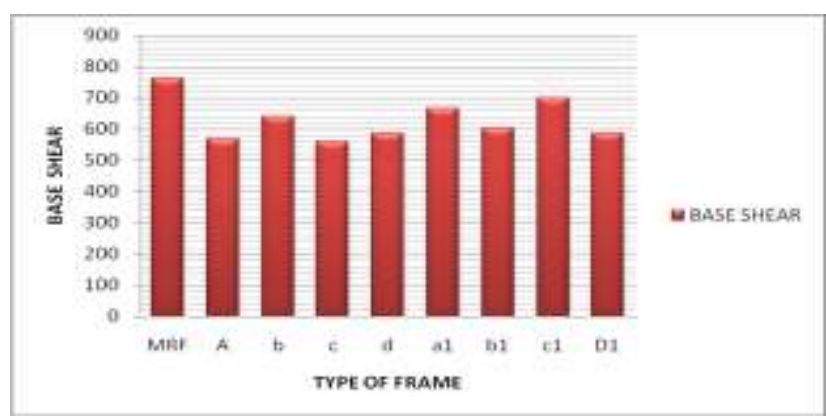

TABLE VII: Displacement details

\begin{tabular}{|c|c|c|}
\hline SR.NO. & TYPE OF FRAME & DEMAND \\
\hline 1 & MRF & 15.6 \\
\hline 2 & A & 9.2 \\
\hline 3 & B & 7.6 \\
\hline 4 & C & 7.3 \\
\hline 5 & D & 6.5 \\
\hline 6 & A1 & 7.8 \\
\hline 7 & B1 & 7.2 \\
\hline 8 & C1 & 7.7 \\
\hline 9 & D1 & 6.5 \\
\hline
\end{tabular}




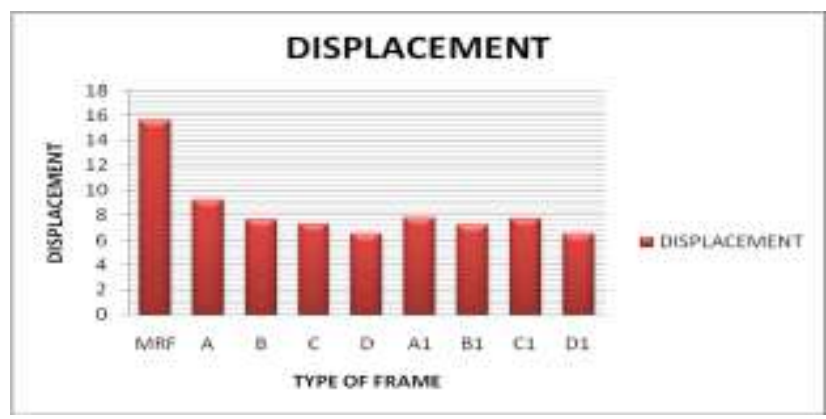

TABLE VIII: Ductility Details

\begin{tabular}{|c|c|c|}
\hline SR.NO. & TYPE OF FRAME & DUCTILITY \\
\hline 1 & MRF & 1.144 \\
\hline 2 & $\mathrm{~A}$ & 2.462 \\
\hline 3 & $\mathrm{~B}$ & 4.149 \\
\hline 4 & $\mathrm{C}$ & 2.171 \\
\hline 5 & $\mathrm{D}$ & 2.364 \\
\hline 6 & $\mathrm{~A}_{1}$ & 2.636 \\
\hline 7 & $\mathrm{~B}_{1}$ & 3.165 \\
\hline 8 & $\mathrm{C}_{1}$ & 3.348 \\
\hline 9 & $\mathrm{D}_{1}$ & 1.995 \\
\hline
\end{tabular}

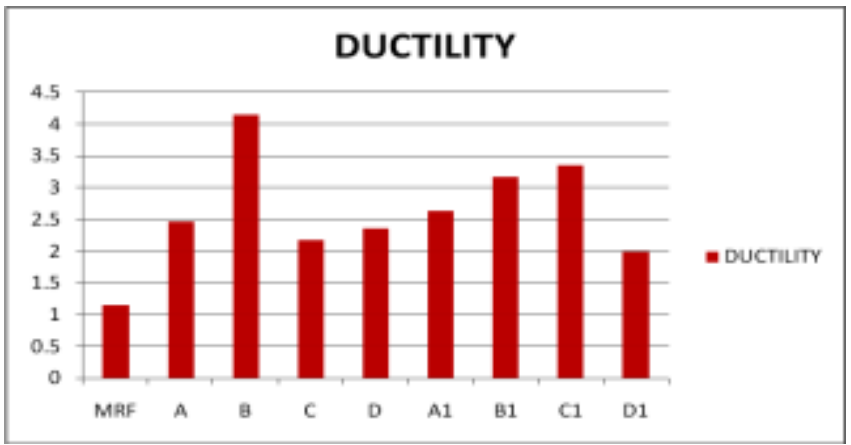

\section{Conclusions}

From analysis of different type of knee braced frame following points are observed

a) Displacement demand of knee braced frame is much lower compared to ordinary moment resisting frame (MRF)

b) Knee braced frame are subjected less base shear compared to MRF.

c) Pattern of hinge formation is limited to secondary knee element which can be replaced after damage thereby preventing damage to main component of structure.

d) Storey drift can be controlled by increasing size of knee element.

e) Existing building with low seismic strength can be strengthened using knee and brace element and their seismic performance can be improved.

f) Comparing the tables VI, VII,VIII, we can study the behaviour patterns of the knee brace frames, such as Base Shear, Displacement, Ductility and likewise the most optimum knee braced frame model can be selected according to the requirements considering economy and practical feasibility. 


\section{References}

[1] M. Mofid, M. lotfollahi, ”On the Characteristics of New Ductile Knee Bracing System,” journal of Constructural Steel, Research 62, 2006, pp 271- 281

[2] C. W. Roeder and E. P. Popov, "Eccentrically Braced Steel Frames for Earthquakes," J.Struct. Div. ASCE, 104(ST7), 1978, pp 391411

[3] J. D. Aristizabal-Ochao, "Disposable Knee Bracing: Improvement in Seismic Design of Steel Frames,” J. Struct. Engg., ASCE, No. 7, 112, 1986, pp 1544-1552.

[4] T. Balendra, M. T. Sam, and C. Y. Liaw, "Diagonal Brace with Ductile Knee Anchor for Aseismic Steel Frame," Earthquake Engg. Struct. Dyn., No. 6, 19, 1990, pp 847-858.

[5] T. Balendra, Lim EL, Lee SL, "Ductile Knee Braced Frames with Shear Yielding Knee for Seismic Resistant Structures," Engineering Structures, 1994, Vol 16(4), pp 263-9.

[6] P. Khosravi and M. Mofid, "Non-linear analysis of disposable knee Bracing," Computers and Structures 75, 2000, pp 65-72

[7] M. Mofid, and P. Khosravi, "Non-linear analysis of dispoable knee Bracing,"Computers \& Structures, 75, 2000 , pp 65-72.

[8] Chia-Ming Uang,"Establishing R (OR RW) and Cd Factors for Building Seismic Provisions,” Journal of Structural Engineering, Vol. 117, No. 1, January, 1991

[9] E. Miranda, "Site Dependent Strength Reduction Factor," ASCE, Journal of Structural Engineering, Vol.119, No.12, 1993. World Academy of Science, Engineering and Technology 502009938

[10] FEMA 273, FEMA 356 , (Federal Emergency Management Agency document)

[11] SAP 2000, Finite element Analysis Software.

[12] Indian Standard IS1893 IS800 (Indian standard code of practice for earthquake resistant design of structure), Bureau of Indian Standards, New Delhi. 